
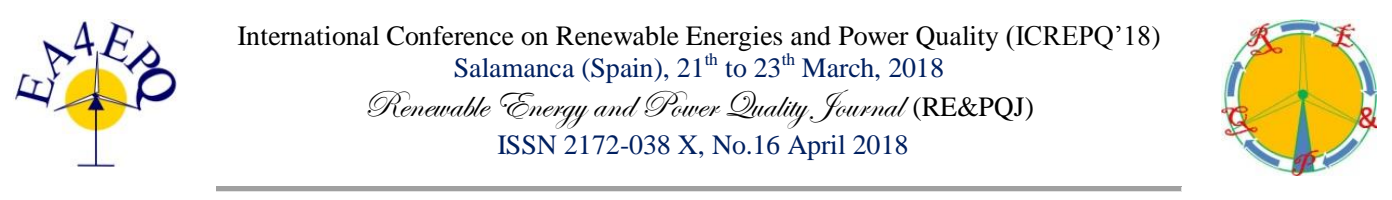

\title{
Multi-Energy Management System for Chungming Island in China
}

\author{
L. Shen ${ }^{1}$, S. Zhang ${ }^{2}$, C. Feng ${ }^{3}$ and A. Pourmovahed ${ }^{4}$ \\ ${ }^{1}$ Visiting SAIC Scholar \\ Phone number: 86-21-22011048, e-mail: shenling@saicmotor.com \\ ${ }^{2}$ Visiting SAIC Scholar \\ Phone number: 86-13816095962, e-mail: zhangsiqi@ saicmotor.com \\ ${ }^{3}$ Visiting SAIC Scholar \\ Phone number: 86-13761635380, e-mail: fengcheng@saicmotor.com \\ ${ }^{4}$ Professor \\ Phone number: 001810 762-9758, e-mail: apourmov@ kettering.edu \\ Kettering University \\ Flint, Michigan, U.S.A. 48504
}

\begin{abstract}
The Shanghai government intends to transform Chungming Island in China into a green ecological base. As a part of this idea, vehicles on this island are preferred to be electric or fuel cell vehicles in order to achieve zero emissions. The design will use SAIC fuel cell buses and commercial vehicles (minibuses) to serve as tour buses and shuttle minibuses. A multi-energy management system was studied for use on this island. This system will support a fuel cell transit bus tour and a shuttle minibus route. The island's demand for hydrogen, according to the parameters of the vehicles and the routes, was determined to be $100 \mathrm{~kg} /$ day. The hydrogen will be produced through electrolysis on location. A $750 \mathrm{~kW}$ wind generator set and a PV roof can be used as the energy supply system. This system can meet the fuel cell bus energy demand ( $950 \mathrm{MWh} /$ year) and serve the local community as well. The total cost of the system is estimated to be 3.0 Million \$US.
\end{abstract}

\section{Key words}

Energy Management, Fuel Cells, Hydrogen Economy, Sustainable Energy

\section{Introduction}

This study reports the results of a team project completed by three Chinese scholars employed by SAIC and enrolled in a 500-level Energy and the Environment course at Kettering University during the Fall Term, 2016.

China's vehicle ownership exceeded 200 million recently. Facing excessive air pollution and an overuse of resources, automobile companies are under pressure to reduce fuel consumption and emissions. As a socially responsible company, Shanghai Automotive Industry Corporation (SAIC) started to research and develop alternatively fueled vehicles in 2001. As these vehicles are continually brought to market, users and enterprises face infrastructural problems.

Purely electric vehicles and some hybrid vehicles need charging stations and fuel cell vehicles require hydrogen refueling stations. The process of electricity and hydrogen production has always been controversial in terms of environmental protection. Considering total carbon emissions during the whole life cycle of a vehicle, SAIC intends to design a clean, low-carbon management system to ensure that the steps of vehicle manufacturing, distribution, use and recycle are all environmentally friendly. This system will service not only new-energy vehicles, but will also benefit the surrounding communities, buildings and residents. Chungming Island, at a distance of $50 \mathrm{~km}$ from

Table I. - Nomenclature

\begin{tabular}{|c|c|}
\hline c & specific heat \\
\hline CHP & combined heat and power \\
\hline FC & fuel cell \\
\hline HHV & higher heating value \\
\hline
\end{tabular}




\begin{tabular}{|c|c|}
\hline $\mathrm{m}$ & mass \\
\hline $\mathrm{N}$ & number of moles \\
\hline $\mathrm{p}$ & pressure \\
\hline $\mathrm{PV}$ & photovoltaic \\
\hline $\mathrm{Q}$ & heat \\
\hline $\mathrm{R}_{\mathrm{u}}$ & universal gas constant \\
\hline $\mathrm{T}$ & temperature $(\mathrm{K})$ \\
\hline $\mathrm{V}$ & volume \\
\hline$\rho$ & density of hydrogen \\
\hline
\end{tabular}

Shanghai mainland, is China's third largest island. It is connected to Shanghai through a bridge and a tunnel. The island is located in the Yangtze River estuary where wind and sunshine are abundant. The Shanghai government intends to transform the island into a green ecological base. As a part of this idea, vehicles on this island are preferred to be electric or fuel cell vehicles in order to achieve zero emissions. Renewable energy will be used as the main source of electricity for electrolysis of water and hydrogen production. Hydrogen bottles, batteries and hot water packages are used as energy storage units.

\section{System Design}

In order to effectively begin designing the system and the location and capability of the charging station, it was necessary to set some design parameters. Eight (8) popular spots on the island were chosen to set up a green line tour (Fig. 1) such as the Chong Ming National Forest Park, Wetland Park and so on, and set up yellow line tour (Fig. 1) between the island's major inside transfer center and the transport hub.

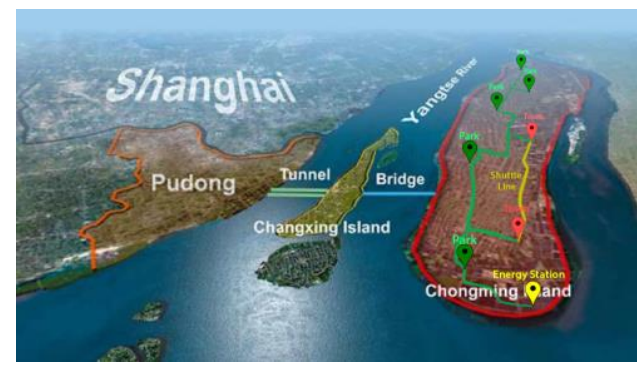

Fig. 1. Green line tour (transit bus) and yellow line tour (shuttle vehicle)

\section{A. Parameters}

Google Maps were used to measure the distance for these two routes (Table II).

Table II. - Parameters of Operation

\begin{tabular}{|c|c|c|c|}
\hline \multicolumn{2}{|c|}{ Bus Tour } & \multicolumn{2}{c|}{ Minibus Tour } \\
\hline Distance(km/tour) & 127 & Distance(km/tour) & 52 \\
\hline
\end{tabular}

It was determined that our design would use SAIC fuel cell buses and commercial vehicles to serve as tour buses and shuttle vehicles (Fig. 2). Using data for these two types of vehicles, the fuel demand was calculated (Table III).

Table III. - Vehicle Design Parameters

\begin{tabular}{|c|c|c|c|}
\hline \multicolumn{2}{|c|}{ Fuel Cell Transit Bus } & \multicolumn{2}{|c|}{ Fuel Cell Shuttle Vehicle } \\
\hline $\begin{array}{c}\mathrm{H}_{2} \text { Consumption } \\
(\mathrm{kg} / 100 \mathrm{~km})\end{array}$ & 7.7 & $\begin{array}{c}\mathrm{H}_{2} \text { Consumption } \\
(\mathrm{kg} / 100 \mathrm{~km})\end{array}$ & 2.7 \\
\hline Number of buses & 4 & Number of Vehicles & 8 \\
\hline Speed $(\mathrm{km} / \mathrm{hr})$ & 40 & Speed $(\mathrm{km} / \mathrm{hr})$ & 55 \\
\hline
\end{tabular}

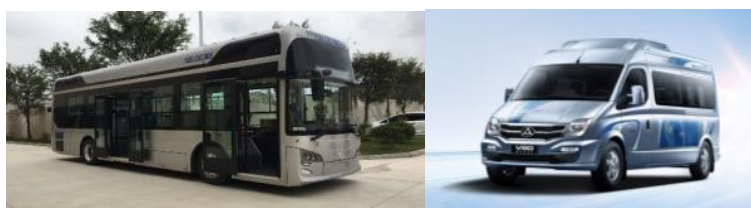

Fig. 2. FC transit bus (L) and FC shuttle vehicle (R)

\section{B. Schedule}

Once the location of the lines and their respective lengths had been determined, it was necessary to determine operation requirements including operation time and number of shifts. The operation time was determined from the distance and the speed of vehicles:

$$
\text { OperationTime }=\text { Distance } / \text { Speed }
$$

Operation time of the fuel cell bus per tour $=127 / 40$ 3 hours . Operation time of the fuel cell commercial vehicle per tour $=52 / 55 \sim 1$ hour

Assuming the operation times are from 7:00 to 18:00, the schedules for these two lines were developed as shown in Table IV.

Table IV. - Schedule for the Two Lines

\begin{tabular}{|c|c|c|c|c|c|c|c|}
\hline Bus & \multicolumn{2}{|c|}{$\begin{array}{l}\text { Schedule of } \\
\text { Transit Bus }\end{array}$} & Shuttle & \multicolumn{4}{|c|}{ Schedule of Shuttle Bus } \\
\hline \multirow{3}{*}{$\# 1$} & $7: 00$ & 13:00 & $\# 1$ & $7: 00$ & $10: 00$ & $13: 30$ & $15: 30$ \\
\hline & - & - & & - & - & - & - \\
\hline & $10: 30$ & $16: 30$ & \#2 & 8:00 & 11:00 & $14: 30$ & $16: 30$ \\
\hline \multirow{3}{*}{ \#2 } & $7: 30$ & $13: 30$ & \#3 & 7:30 & $10: 30$ & 14:00 & $16: 00$ \\
\hline & - & - & & - & - & - & - \\
\hline & 11:00 & $17: 00$ & \#4 & 8:30 & $11: 30$ & 15:00 & $17: 00$ \\
\hline \multirow{3}{*}{ \#3 } & $8: 00$ & $14: 00$ & $\# 5$ & $8: 00$ & $11: 00$ & $14: 30$ & $16: 30$ \\
\hline & - & - & & - & - & - & - \\
\hline & 11:30 & $17: 30$ & \#6 & 9:00 & $12: 00$ & $15: 30$ & $17: 30$ \\
\hline \multirow{3}{*}{ \#4 } & $8: 30$ & $14: 30$ & \#7 & $9: 30$ & 13:00 & $15: 00$ & $17: 00$ \\
\hline & - & - & & - & - & - & - \\
\hline & $12: 00$ & $18: 00$ & \#8 & $10: 30$ & $14: 00$ & $16: 00$ & $18: 00$ \\
\hline
\end{tabular}


Operation parameters are shown in Table V.

Table V. - Operation Parameters

\begin{tabular}{|c|c|c|c|}
\hline \multicolumn{2}{|c|}{$\begin{array}{c}\text { Operation Parameters of } \\
\text { Fuel Cell Transit Bus }\end{array}$} & \multicolumn{2}{|c|}{$\begin{array}{c}\text { Operating Parameters of } \\
\text { Fuel Cell Shuttle Bus }\end{array}$} \\
\hline $\begin{array}{c}\text { Operation time } \\
\text { (hr/Tour) }\end{array}$ & 3.5 & $\begin{array}{c}\text { Operation time } \\
\text { (hr/Tour) }\end{array}$ & 1 \\
\hline Shift (Tour/Day) & 8 & Shift (Tour/Day) & 16 \\
\hline
\end{tabular}

\section{Hydrogen Demand}

To ensure that the operation of fuel cell buses and shuttle vehicles is executed under schedule, the hydrogen consumption needed to be calculated. The equation used to calculate this value is:

Hydrogen consumption $=$ number of shifts $\mathrm{x}$ hydrogen consumption/100 km x operation distance/100

Hydrogen consumption of fuel cell buses $=8 * 7.7 *(127 / 100)$ $=78 \mathrm{~kg} / \mathrm{day}$

Hydrogen consumption of fuel cell commercial vehicles $=$ $16 * 2.7 *(52 / 100)=22 \mathrm{~kg} /$ day

Total hydrogen demand $=78+22=100 \mathrm{~kg} /$ day

The combination of a tunnel and a bridge are the only way connecting the island and the mainland. They cannot be used for hydrogen transportation due to a prohibition issued by the government for safety

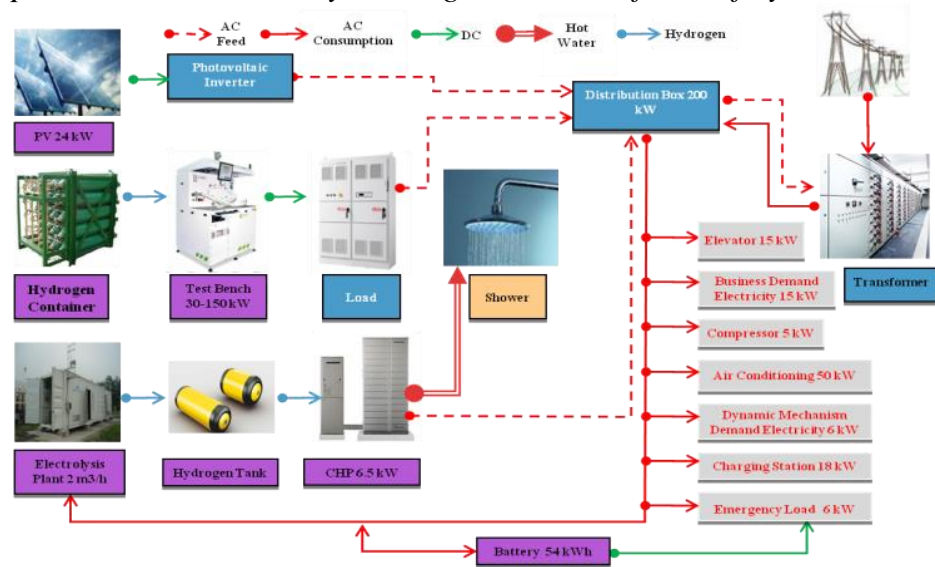

Fig. 3. Circuit and architecture of the building multi-energy management system reasons. The island is to be established as a "green island" hence no chemical industry will be developed on this island. The hydrogen needed (100 kg/day) should be produced through electrolysis on location.

\section{System Specifications}

In order to verify the feasibility of the system, a smallscale simulated physical system was set up in an office building. This building belongs to a fuel cell system assembly company (Re-Fire Technology). The simulation system includes 6 modules: solar power, electrolysis, fuel cell CHP (combined heat and power), hydrogen storage, batteries and a test bench. It was assumed that solar power, as a renewable and primary source, is used to generate electricity. Electrolysis is used to produce hydrogen, and hydrogen storage and batteries are used as storage units. Considering that one of the businesses of this company is testing power systems, an existing test bench they already own is arranged as the load of the simulation system which can be simply regarded as the hydrogen charging station in the real system. The basic circuit and architecture shown in Fig. 3 was created. This allowed us to easily determine the electricity demand for electrolysis as well as other power requirements. Simulation system layout on the building is shown in Fig. 4.

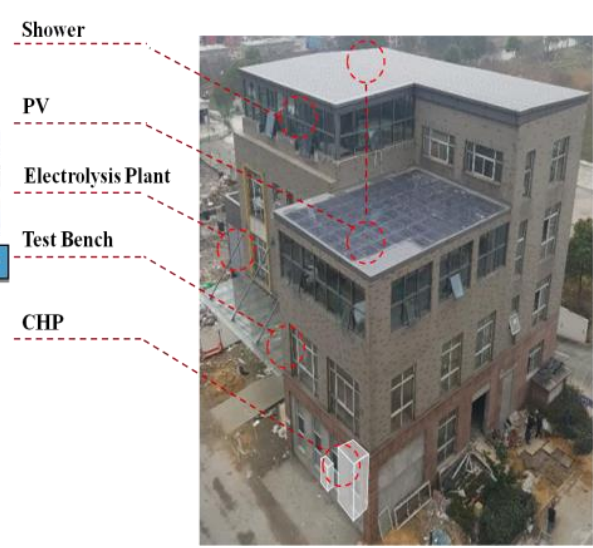

Fig. 4. Simulation system layout on the building 


\section{Calculations}

\section{A. Module 1: Solar power}

Two hundred ninety eight (298) 80-W (each) polycrystalline silicon photovoltaic panels have been installed on the roof of the building.

Roof area $=600 \mathrm{~m}^{2}$

Area of one panel $=1 \mathrm{~m} \times 1 \mathrm{~m}=1 \mathrm{~m}^{2}$

Effective roof area $=50 \%$ of actual roof area $=300 \mathrm{~m}^{2}$

The number of photovoltaic panels that could actually be installed is 298 .

According to the Renewable Energy Data Manual, released by China National Renewable Energy Centre (2015), the effective (annual average) sunshine time is 3.08 hours per day in Shanghai.

The theoretical power of total photovoltaic panel $=298$ $* 80 \mathrm{~W} * 3.08=73.4 \mathrm{~kW} . \mathrm{h} /$ day

The electric power consumption of the auxiliary equipment is $9 \mathrm{~kW}$.

Figs. 5 and 6 show the employee gym equipment with solar panels as well as the electrolysis equipment and its specifications.

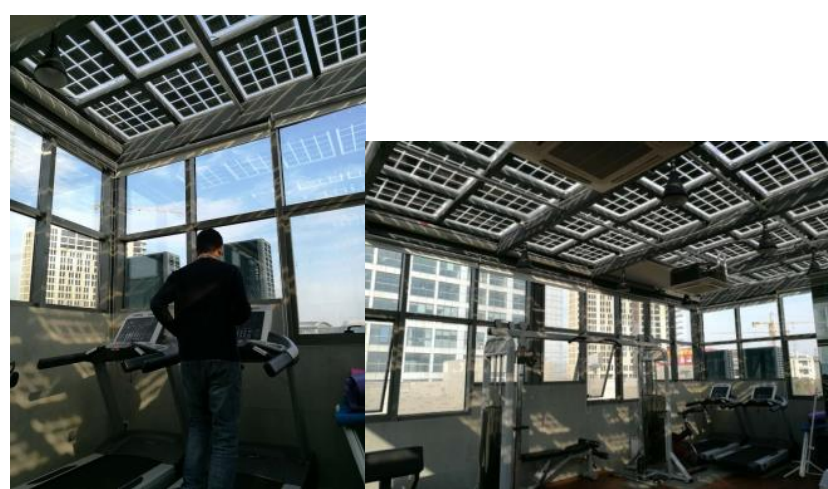

Fig. 5. GYM with photovoltaic panel roof

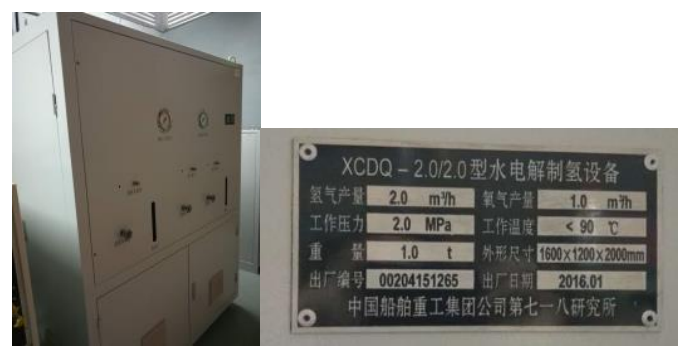

Fig. 6. Electrolysis equipment and its specifications

\section{B. Module 2: Electrolysis}

As shown in Fig. 6, the electrolysis equipment capability is $2.0 \mathrm{~m}^{3} / \mathrm{h}$ of hydrogen. Its electric power consumption is $4.2 \mathrm{~kW}$.
For an ideal gas, the number of moles and volume are related by the ideal gas equation of state:

$$
\mathrm{PV}=\mathrm{NR}_{\mathrm{u}} \mathrm{T}
$$

At standard conditions, $101.3 \mathrm{kPa}$ and $0{ }^{\circ} \mathrm{C}$, the molar volume is:

Molecular mass of Hydrogen is $2.0158 \mathrm{~kg} / \mathrm{kmol}$. The density of hydrogen is calculated as:

$$
\rho=0.0899 \mathrm{~kg} / \mathrm{m}^{3}
$$

Operation time of the equipment for each day is 16 hours (two 8-hour shifts). The amount of hydrogen it can produce is:

$$
2.0 \mathrm{~m}^{3} / \mathrm{h} \times 16 \mathrm{~h} / \text { day x } 0.0899 \mathrm{~kg} / \mathrm{m}^{3}=2.88 \mathrm{~kg} / \text { day }
$$

Actual hydrogen required by the vehicles is $100 \mathrm{~kg} / \mathrm{day}$.

The power consumed by the electrolysis equipment is 4.2 $\mathrm{kW}$, Electricity demand per day is:

$$
4.2 \times 16=67.2 \mathrm{kWh}
$$

\section{Module 3: Fuel Cell CHP}

A PEM fuel cell is an electrochemical device which brings hydrogen and air together and produces direct electricity, water and heat. The Fuel Cell module used in the smallscale simulated system (not pictured) has an output power of $6.5 \mathrm{~kW}$, and an output voltage of 40-75 Volts. Hydrogen consumption is $0.325 \mathrm{~kg} / \mathrm{hr}$.

The basic fuel cell reactions are [1],[2]:

$$
\begin{aligned}
& \text { At the anode: } \\
& \text { At the cathode: } \frac{1}{2} \mathrm{O}_{2} \rightarrow 2 \mathrm{H}^{+}+2 \mathrm{H}^{+}+2 \mathrm{e}^{-} \rightarrow \mathrm{H}_{2} \mathrm{O}
\end{aligned}
$$

The overall reaction is the same as the reaction of hydrogen combustion, which means that there is energy released in the process:

Overall: $\mathrm{H}_{2}+\frac{1}{2} \mathrm{O}_{2} \rightarrow \mathrm{H}_{2} \mathrm{O}+$ heat + electricity

At standard conditions, that is $101.3 \mathrm{kPa}$ and $0^{\circ} \mathrm{C}$, the heat released is:

$$
\mathrm{HHV}=141.8 \mathrm{MJ} / \mathrm{kg}
$$

Total heat supplied by fuel cell CHP is:

$$
141.8 \times 0.325=46.12 \mathrm{MJ} / \mathrm{h}=12.8 \mathrm{~kW}
$$

Specific heat of water is $4.186 \mathrm{~kJ} /\left(\mathrm{Kg}{ }^{\circ} \mathrm{C}\right)$. This means that to heat $1 \mathrm{~kg}$ water by $1^{\circ} \mathrm{C}, 4.186 \mathrm{KJ}$ of heat is needed. It was assumed that the water inlet temperature is $15^{\circ} \mathrm{C}$, and suitable shower temperature should be around $37^{\circ} \mathrm{C}$ which is close to the human body temperature. We need to heat the water by $22{ }^{\circ} \mathrm{C}$. One $\mathrm{kg}$ of hydrogen can release 141.8 MJ of heat, which can heat the water by $22{ }^{\circ} \mathrm{C}$ : 


$$
\mathrm{Q}=\mathrm{mc} \Delta \mathrm{T}
$$

$46.12 * 1000=m * 4.186 * 22$

$m=501 \mathrm{~kg}$ of water

The hot water tank is shown in Fig. 7 (L).

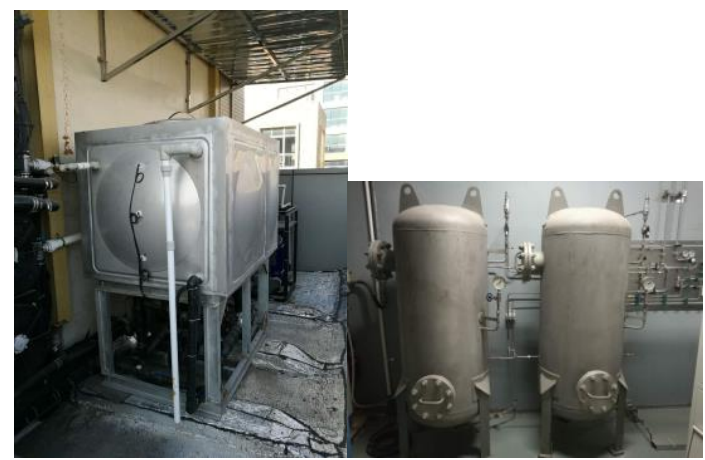

Fig. 7. Hot water tank (L) and Main hydrogen storage tanks (R)

\section{Module 4: Hydrogen storage}

Figs. 7 (R) and 8 show the main and the spare hydrogen storage tanks.

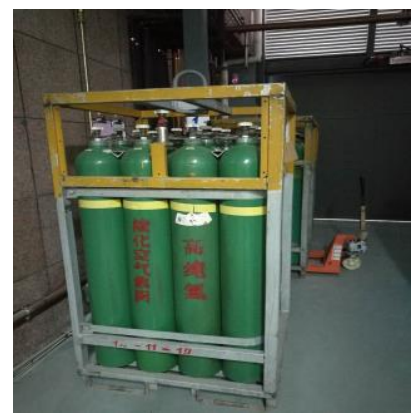

Fig. 8. Spare hydrogen storage tanks

The two $6-\mathrm{m}^{3}$ main tanks shown in Fig. $7(\mathrm{R})$ store hydrogen produced by electrolysis, especially at night during the off-peak hours. The electric power consumed to keep the two tanks pressurized is $1 \mathrm{~kW}$.

\section{E. Module 5: Battery}

Three (3) battery packages were used. One of them is shown in Fig. 9 (L). Each can store $18 \mathrm{kWh}$. Together, they can store $54 \mathrm{kWh}$ at the night. The control box is shown in Fig. 9 (R).

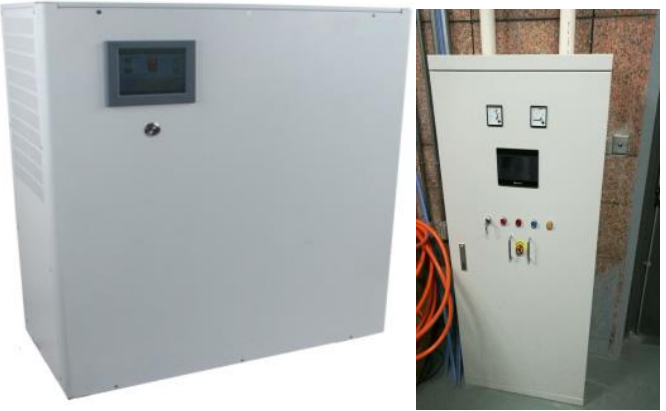

Fig. 9. Battery (L) and Control box (R)

\section{F. Module 6: Test bench}

The test bench and a fuel cell stack are shown in Fig. 10 . Re-Fire Technology uses the test bench to test performance of different fuel cell stacks with an output power of 30-150 kW. Hydrogen consumption for $30 \mathrm{~kW}$ of power is $1.5 \mathrm{~kg} / \mathrm{h}$. The heat produced is:

$$
141.8 \times 1.5=212.7 \mathrm{MJ} / \mathrm{h}=59 \mathrm{~kW}
$$

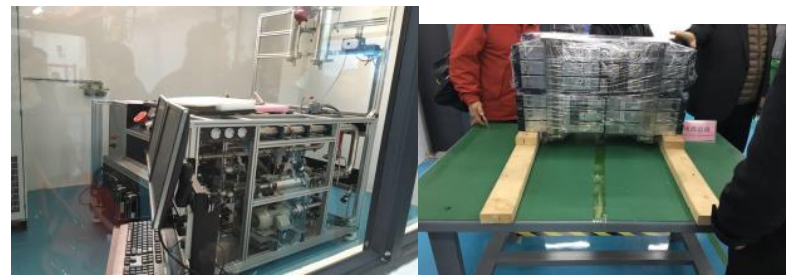

Fig. 10. Test bench (L) and a fell cell stack (R)

The parameters used for the simulation are shown in Table VI. It is obvious that solar energy can support the electricity demand of electrolysis, but the capacity of electrolysis does not meet the demand for hydrogen.

\begin{tabular}{|c|c|c|c|c|c|c|}
\hline & Electrolysis & Batt. & $\begin{array}{c}\text { FC } \\
\text { CHP }\end{array}$ & $\begin{array}{l}\text { Solar } \\
\text { Power }\end{array}$ & $\begin{array}{c}\mathrm{H}_{2} \\
\text { Storage }\end{array}$ & $\begin{array}{c}\text { Test } \\
\text { bench }\end{array}$ \\
\hline Power & & & $6.5 \mathrm{~kW}$ & $\begin{array}{c}73.4 \\
\mathrm{~kW} . \mathrm{h} \\
\text { /day }\end{array}$ & & \\
\hline Capacity & $\begin{array}{l}2.0 \mathrm{~m}^{3} / \mathrm{hr} \text { or } \\
2.88 \mathrm{~kg} / \text { day }\end{array}$ & $\begin{array}{c}54 \\
\mathrm{kWh}\end{array}$ & $\begin{array}{l}6.5 \\
\mathrm{~kW}\end{array}$ & & $\begin{array}{l}12 \mathrm{~m}^{3} \text { or } \\
1.08 \mathrm{~kg}\end{array}$ & $\begin{array}{r}30- \\
150 \\
\mathrm{kWh} \\
\end{array}$ \\
\hline $\begin{array}{l}\text { Consu- } \\
\text { mption }\end{array}$ & $\begin{array}{c}4.2 \mathrm{~kW} \\
(16 \mathrm{~h} / \text { day })\end{array}$ & & $\begin{array}{c}0.325 \\
\mathrm{~kg} / \mathrm{h}\end{array}$ & $\begin{array}{c}9 \mathrm{kWh} / \\
\text { day } \\
\text { (accesso } \\
\text { ries) }\end{array}$ & $\begin{array}{l}1 \mathrm{kWh} / \\
\text { day }\end{array}$ & $\begin{array}{c}1.5 \\
\mathrm{~kg} / \mathrm{h} \\
@ 30 \\
\mathrm{~kW}\end{array}$ \\
\hline $\begin{array}{c}\text { Avail. } \\
\text { Heat }\end{array}$ & & & $\begin{array}{l}12.8 \\
\mathrm{~kW}\end{array}$ & & & $59 \mathrm{~kW}$ \\
\hline
\end{tabular}

Table VI. - System Specifications

\section{Test Data}

The physically simulated system was operated and data for October 3-23, 2016 were recorded. The data included solar energy supply, fuel cell supply, and hydrogen supply. The data is shown in Fig. 11. 


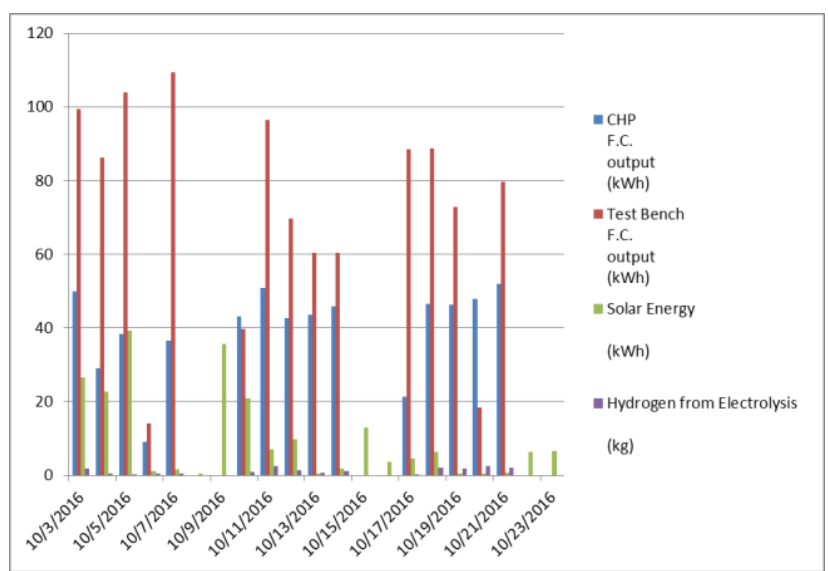

Fig. 11. Test data for October 3-23, 2016

Table VII shows the physically-simulated system specifications. The hydrogen needed (100 kg/day) should be produced through electrolysis on location.

Table VII. - Specifications of the actual system in Chungming Island

\begin{tabular}{|l|c|c|c|c|}
\hline & Electrolysis & Solar Power & $\begin{array}{c}\mathrm{H}_{2} \\
\text { Storage }\end{array}$ & $\begin{array}{c}\text { Wind \& } \\
\text { Grid } \\
\text { Accessor- } \\
\text { ies }\end{array}$ \\
\hline Capacity & $100 \mathrm{~kg} /$ day & $\begin{array}{c}73.4 \\
\mathrm{kWh} / \text { day }\end{array}$ & $20 \mathrm{~kg}$ & $\begin{array}{c}2638 \\
\mathrm{kWh} / \text { day }\end{array}$ \\
\hline $\begin{array}{l}\text { Consu- } \\
\text { mption }\end{array}$ & $\begin{array}{c}2333 \mathrm{kWh} \\
\text { per day }\end{array}$ & $\begin{array}{c}20 \% \text { of } \\
\text { capacity is } \\
\text { used by } \\
\text { accessori- } \\
\text { es }\end{array}$ & $\begin{array}{c}20 \\
\mathrm{kWh} / \text { day } \\
\text { used for } \\
\mathrm{H}_{2} \\
\text { compress- } \\
\text { ion }\end{array}$ & $\begin{array}{c}15 \% \text { of } \\
\text { capacity }\end{array}$ \\
\hline
\end{tabular}

Solar power with a photovoltaic panel area of $298 \mathrm{~m}^{2}$ can only supply 73.4 out of $2333 \mathrm{kWh} /$ day $(3 \%)$ of the electricity demand for electrolysis if the energy needed to serve the community is to be supplied. Wind power and the grid should be used as the main sources of energy. The capacity of wind power and the grid should be at least $(2333-73.4+14+20)^{*} 1.15=2638 \mathrm{kWh} /$ day to satisfy the energy demand of fuel cell vehicles running on the two routes.

These results show that PV based power is not reasonable for the scale of the real system in Chungming Island. As an Island with abundant wind, wind power and the grid should be used as main sources of energy. Hydrogen produced by electrolysis is not economical because of the double conversion of electrical energy. Power density and efficiency should be considered when choosing an energy storage unit [3].

\section{Energy Source Data for the Island}

Nine wind farms have been built on Chungming Island since 2007, with a total installed capacity of $291 \mathrm{MW}$. The annual generating capacity is up to $0.6 \mathrm{TWh}$. Wind speed in the Chungming inland area is approximately 3.5-4.0 $\mathrm{m} / \mathrm{s}$. Wind speed around Chungming-Dongtan, Hengsha Island and the Yangtze River Estuary is 5.5-6.0/s.
The total annual generation can be calculated through the ampere-hour of the wind power generator by gathering data systematically. According to the records of Changxing Power Company, Island wind power generation operating time was more than 2700 hours last year.

Chungming photovoltaic applications started earlier than any other area. China's first commercial operation of photovoltaic 1 MW avant-garde photovoltaic power station was located in Chungming Island in 2007. During the past two years, with the national and Shanghai PV subsidy policy being introduced, 8 enterprise distributed PV projects and 50 personal distributed photovoltaic projects have been built, with a total installed capacity of $3400 \mathrm{~kW}$. Chungming Island has been categorized as a Class-3 type area for solar energy. According to the local government, a PV system with $1 \mathrm{~kW}$ of power can generate $1100 \mathrm{kWh}$ of electric energy per year in this area.

\section{Economic Analysis}

According to [5], the 2013 cost to build a solar power station in China is as shown in Table VIII:

Table VIII. - 2013 cost of a solar power station in China

\begin{tabular}{|c|c|c|c|c|}
\hline Item & $\begin{array}{l}\text { US\$ } \\
/ \mathbf{k W}\end{array}$ & $\begin{array}{l}\text { Decrease } \\
\text { Relative } \\
\text { to } \\
\text { Previous } \\
\text { Year }\end{array}$ & Equipment & Price \\
\hline $\begin{array}{l}\text { Equipment \& } \\
\text { Installation }\end{array}$ & 1952 & $8.4 \%$ & PV Module & $\begin{array}{c}0.99 \\
\text { US\$/W }\end{array}$ \\
\hline $\begin{array}{l}\text { Constructional } \\
\text { Engineering }\end{array}$ & 240 & $9.7 \%$ & $\begin{array}{l}\text { Inverter } \\
\text { System }\end{array}$ & $\begin{array}{l}490,000 \\
\text { US\$/set }\end{array}$ \\
\hline Other Expenses & 157 & $52.1 \%$ & & \\
\hline $\begin{array}{l}\text { Basic Reserve } \\
\text { Funds }\end{array}$ & 36 & $94.3 \%$ & & \\
\hline $\begin{array}{l}\text { Loan Interest in } \\
\text { a Construction } \\
\text { Cycle }\end{array}$ & 43 & $28.5 \%$ & & \\
\hline $\begin{array}{l}\text { Total } \\
\text { Investment }\end{array}$ & 2430 & $13.0 \%$ & & \\
\hline
\end{tabular}

(Source: [5] The statistics assessment report of construction of solar power generation in China 2013, page 35, page 39, National Energy Administration of China, US Dollar vs. China Yuan = 1:7)

Based on the calculations, the electricity consumption for running fuel cell vehicles in Chungming Island is 2638 $\mathrm{kWh}$ /day. Assume running 360 days per year; the total consumption is:

$$
2638 \mathrm{kWh} / \text { day } * 360 / 1000=950 \mathrm{MWh} / \text { year }
$$

A fully operational wind generating set with a power capacity of $750 \mathrm{~kW}$ (operating 2700 hours/year) can generate:

$750 \mathrm{~kW} * 2700 \mathrm{hr} *(1 \mathrm{MW} / 1000 \mathrm{~kW})=2025 \mathrm{MWh} /$ year 
In this study, a roof area of $600 \mathrm{~m}^{2}$ was used, resulting in $73.4 \mathrm{~kW} . \mathrm{h} /$ day:

$73.4 \mathrm{~kW} . \mathrm{h} /$ day $* 1100$ operating hours/year $=80.7$ MWh/year

A $750 \mathrm{~kW}$ wind generator set and the PV roof can be used as the energy supply system. This system can meet the fuel cell bus operation demand (950 MWh/year) and can serve the local community as well.

Taking 1304 \$US/kW as unit cost of wind power generation, $471 \$ \mathrm{US} / \mathrm{kW}$ as unit cost of additional wind power equipment, with a 75-ton tower (\$US 1460/ton) [4],[5] the cost of the wind power system is estimated to be:

$(1304 * 750)+(471 * 750)+(1460 * 75)=1.44$ Million \$US

Cost for procurement of the solar power system and construction of the facility is:

$2430 \mathrm{US} \$ / \mathrm{kW} * 298$ panels $* 80 \mathrm{~W} /$ panel $/ 1000=0.06$ Million \$US.

The breakdown of the total cost of the multi-energy power system in Chungming is shown in Table IX.

Table IX. - Cost and lifetime of the multi-energy system in Chungming Island

\begin{tabular}{|l|l|l|}
\hline ITEM & COST & UNIT \\
\hline Compressor & 228,571 & US\$ \\
\hline Compressor Life & 10 & years \\
\hline Medium Pressure Storage & 214,285 & US\$ \\
\hline Storage Life & 20 & years \\
\hline High Pressure Storage & 214,285 & US\$ \\
\hline Storage Life & 20 & years \\
\hline Dispenser Cost & 128,571 & US\$ \\
\hline Dispenser Life & 10 & years \\
\hline Electrolysis Cost & 428,571 & US\$ \\
\hline Electrolysis Life & 10 & years \\
\hline Controller Cost $¥ 100,000$ & 142,857 & US\$ \\
\hline Building Cost & 71,428 & US\$ \\
\hline Construction Cost $¥ 100,000$ & 142,857 & US\$ \\
\hline Other ¥ 100,000 & 142,857 & US\$ \\
\hline Hydrogen Station Life & 20 & years \\
\hline Battery Cost & 571 & US/kWh \\
\hline Battery Capacity & 54 & kWh \\
\hline Battery Package Cost & 30,834 & US\$ \\
\hline Wind Power System & 1.44 million & US\$ \\
\hline Wind System Life & 20 & Years \\
\hline Solar Power system & 0.06 million & US\$ \\
\hline Solar System Life & 25 & Years \\
\hline Total Cost & $\mathbf{3 . 0}$ million & US\$ \\
\hline & & \\
\hline
\end{tabular}

\section{Summary and Conclusions}

- The Shanghai government intends to transform Chungming Island in China into a green ecological base. As a part of this idea, vehicles on this island are preferred to be electric or fuel cell vehicles in order to achieve zero emissions. The design will use SAIC fuel cell buses and commercial vehicles (minibuses) to serve as tour buses and shuttle minibuses.
- A multi-energy management system was studied for use on this island. This system will support a fuel cell transit bus tour and a shuttle minibus route. The island's demand for hydrogen, according to the parameters of the vehicles and the routes, was determined to be $100 \mathrm{~kg} / \mathrm{day}$. The hydrogen will be produced through electrolysis on location.

- In order to verify the feasibility of the system, a smallscale simulated physical system was set up in an office building. This simulated physical system consists of 298 solar PV panels, an electrolysis module, a hydrogen storage module, a battery module, and a test bench used for data collection. Two hundred ninety eight $80-\mathrm{W}, 1 \mathrm{~m} \times 1 \mathrm{~m}$ (each) polycrystalline silicon photovoltaic panels have been installed on the roof of the building. The total maximum capacity of the PV system is $73.4 \mathrm{~kW} . \mathrm{h} /$ day. The electrolysis equipment capability is $2.0 \mathrm{~m}^{3} / \mathrm{h}$ of hydrogen. Its electric power consumption is $4.2 \mathrm{~kW}$. It operates 16 hours per day. Its daily electricity demand is $67.2 \mathrm{~kW} . \mathrm{h}$. The fuel cell module used in the small-scale simulated system has an output power of $6.5 \mathrm{~kW}$. Its hydrogen consumption is $0.325 \mathrm{~kg} / \mathrm{hr}$. Three battery packages are used. Together, they can store $54 \mathrm{kWh}$ at night.

- Based on data collected during autumn, solar power with a photovoltaic panel area of $298 \mathrm{~m}^{2}$ can only supply 73.4 out of $2333 \mathrm{kWh} /$ day $(3 \%)$ of the electricity demand for electrolysis if the energy needed to serve the island community is to be supplied. Wind power and the grid should be used as main sources of energy. The capacity of wind power and the grid should be at least $2638 \mathrm{kWh} /$ day $(950 \mathrm{MWh} /$ year assuming 360 days of operation/year) to satisfy the energy demand of fuel cell vehicles running on the two routes.

- The results show that PV-based power is not reasonable for the scale of the real system on Chungming Island. As an Island with abundant wind, wind power and the grid should be used as main sources of energy. Hydrogen produced by electrolysis is not economical because of the double conversion of energy.

- Nine wind farms have been built on Chungming Island since 2007, with a total installed capacity of 291 MW. The annual generating capacity is up to $0.6 \mathrm{TWh}$. The wind speed in the Chungming inland area is approximately $3.5-4.0 \mathrm{~m} / \mathrm{s}$. Wind speed around Chungming-Dongtan, Hengsha Island and the Yangtze River Estuary is $5.5-6.0 \mathrm{~m} / \mathrm{s}$.

- Chungming Island has been categorized as a Class-3 type area for solar energy. According to the local government, a 1-kW PV system can generate 1100 $\mathrm{kWh}$ of electric energy per year in this area. Based on the calculations, the electricity consumption for running fuel cell vehicles in Chungming Island is 2638 $\mathrm{kWh}$ /day. Assuming 360 days of operation per year, the total consumption is $950 \mathrm{MWh}$ /year. A $750 \mathrm{~kW}$ wind generator set and the PV roof can be used as the 
energy supply system. This system can meet the fuel cell bus operation demand (950 MWh/year) and serve the local community as well.

- Taking 1304 \$US/kW as unit cost of wind power generation, $471 \$ U S / \mathrm{kW}$ as unit cost of additional wind power equipment, with a 75-ton tower (\$US $1460 /$ ton) and including all other equipment (electrolysis, hydrogen storage equipment, batteries, etc.), the total cost of the system is estimated to be 3.0 Million \$US.

\section{References}

[1] F. Barbir, PEM Fuel Cells, Theory and Practice, $2^{\text {nd }}$ ed., 2013.

[2] J. Larminie and A. Dicks, Fuel Cell Systems Explained, $2^{\text {nd }}$ ed., 2003.

[3] J. R. Fanchi, Energy Technology and Directions for the Future, 2004.

[4] Renewable Energy Data Manual, China Nation Renewable Energy Centre, 2014.

[5] Handbook of Renewable Energy issued by the National Energy Administration of China, 2014. 